\title{
Diagnostic value of HE4+ circulating tumor cells in patients with suspicious ovarian cancer
}

\author{
Yan-Xiu Guo ${ }^{1, *}$, Kuang Hong Neoh ${ }^{2, *}$, Xiao-Hong Chang ${ }^{1}$, Yukun Sun², Hong-Yan \\ Cheng ${ }^{1}$, Xue $\mathrm{Ye}^{1}$, Rui-Qiong Ma ${ }^{1}$, Ray P.S. Han ${ }^{2}$ and Heng Cui ${ }^{1}$ \\ ${ }^{1}$ Center of Gynecologic Oncology, Peking University People's Hospital, Beijing, China \\ ${ }^{2}$ College of Engineering, Peking University, Beijing, China \\ *These authors contributed equally to this work \\ Correspondence to: Ray P.S. Han, email: ray-han@pku.edu.cn \\ Heng Cui, email: cuiheng@pkuph.edu.cn \\ Keywords: circulating tumor cells; microfluidic isolation; HE4; ovarian cancer; diagnosis \\ Received: July 21,2017 Accepted: December 27, $2017 \quad$ Published: January 04, 2018 \\ Copyright: Guo et al. This is an open-access article distributed under the terms of the Creative Commons Attribution License 3.0 \\ (CC BY 3.0), which permits unrestricted use, distribution, and reproduction in any medium, provided the original author and source \\ are credited.
}

\section{ABSTRACT}

Lacking a satisfactory screening test, ovarian cancer is frequently diagnosed at a late stage, leading to poor patient outcomes. This study investigated the diagnostic value of circulating tumor cells (CTCs) in peripheral blood from patients with suspected ovarian tumors. Sixty-one women suspected of having an ovarian mass were prospectively enrolled in this study. CTCs were identified and counted using microfluidic isolation and immunofluorescent staining of CD45, HE4, and epithelial and mesenchymal (E\&M) markers (epithelial cell adhesion molecule, cytokeratins, and vimentin). Thirty (49\%) of the patients were diagnosed with ovarian cancer. DAPI+/E\&M+/CD45-/HE4+ CTC counts were higher in these patients than in patients with benign tumors $(p=0.016)$. The receiver operating characteristic $(R O C)$ curve showed that the sensitivity of CTCs was $73.3 \%$, which was superior to that of CA125 (56.7\%). In patients with elevated CA125 levels $(\geq 35 \mathrm{U} / \mathrm{ml})$, CTC counts still showed good specificity (86.7\%). Our findings suggest the DAPI+/E\&M+/CD45-/HE4+ CTC count is a useful diagnostic indicator in patients with suspected ovarian cancer.

\section{INTRODUCTION}

Ovarian cancer is the fifth leading cause of cancer mortality in women [1], and approximately 521,000 new cases were diagnosed in China in 2015 [2]. Because the symptoms of ovarian cancer are fairly non-specific and there is no satisfactory screening test, about $70 \%$ of all ovarian cancer patients are diagnosed at advanced stages [3] with metastases primarily in the peritoneal cavity [4, 5]. These patients usually undergo debulking surgery prior to receiving a combined chemotherapy regimen including a platinum-based drug and taxane [5]. Nevertheless, over $50 \%$ of cases eventually relapse $[3,6]$. Relapse and metastasis are the major contributors to poor overall survival (OS) rates $(<35 \%)$ in advanced ovarian cancer patients [7]. Thus, a method for early detection of relapse and/or metastasis would be highly useful for ovarian cancer patient management and care. Epithelial ovarian cancer metastasis is widely believed to occur via direct surface spread through the peritoneal circulation $[8,9]$. However, recent research also supports the hematogenous route as an important mode of ovarian cancer omental metastasis through a parabiosis model [10].

In the hematogenous route, circulating tumor cells (CTCs), which have shed from solid tumors and intravasated, can circulate throughout the body and attach at distant organs to grow metastatic lesions. CTCs in peripheral blood have been used as predictive biomarkers for early diagnosis and prognosis of ovarian $[4,6,7,11$, 12], breast [13], lung [14], and bladder [15] cancers. CTCs enriched by the cell adhesion matrix (CAM) method showed an $83 \%$ sensitivity and $95 \%$ specificity in detecting ovarian cancer [4]. Various methods have been used to identify and capture CTCs from the peripheral blood, including a physical isolation method that exploits density and/ or size differences and an immunoaffinity-based method 
that targets specific antigen-antibody interactions [16, 17]. Although immunoaffinity-based isolation methods, such as the CellSearch system, have higher capture specificities, some CTC subpopulations may escape detection. Similarly, systems that employ the epithelial cell adhesion molecule (EpCAM), which is the most widely used immunoaffinity antibody, will not identify and capture mesenchymal CTCs that may correlate with metastatic potential [18]. Size-based harvesting methods are more reliable as they are premised on the fact that CTCs $(\sim 10-20 \mu \mathrm{m})$ are larger than normal erythrocytes $(\sim 6-8 \mu \mathrm{m})$ and leukocytes $(\sim 7-12 \mu \mathrm{m})$ [19]. Leukocytes may be captured along with CTCs, but are easily differentiated using CD45. Major CTC detection methods include immunocytochemistry (ICC) [20], reversetranscription polymerase chain reaction (RT-PCR) [21], flow cytometry [22], and fluorescence in situ hybridization (FISH) [16]. Recent work suggests that CTC detection rates in ovarian cancer patients vary widely (12-90\%) across different platforms (Table 1) [5, 7, 10, 16, 17, 21, 22, 25$35]$. This can be attributed to varying capture efficiencies and detection limits, and the use of specific markers. Additionally, most studies have focused on the prognostic value of CTCs rather than their diagnostic value (Table 1).

Human epididymis protein 4 (HE4), encoded by the WFDC2 gene and also known as WAP four-disulfide core domain protein 2 (WFDC2), was first introduced as a potential ovarian cancer biomarker in 2003 [31]. HE4 is overexpressed on the surfaces of epithelial ovarian carcinoma cells, but not on normal ovary cells [32]. Our previous study showed that serum HE4 level had a sensitivity and specificity for ovarian cancer of $73 \%$ and $90-100 \%$, respectively [33], and was superior to CA125 (sensitivity, 88\%; specificity, 36-99\%). We further showed elevated HE4 expression in established ovarian cancer cell lines [29]. We hypothesized that HE4 could be a promising marker for detecting and identifying CTCs and, subsequently, ovarian cancers. The present study established a new, HE4-based immunofluorescence staining strategy using a microfluidic assaying to detect epithelial ovarian cancer CTCs. We found that HE4+ CTCs were more sensitive than CA125 in identifying patients at high risk for ovarian cancer.

\section{RESULTS}

\section{Determining chip capture efficiency using a cancer cell line}

To characterize the cancer cell capture efficiency of the microfluidic chip, small numbers of pre-stained SKOV3ip1 cells $(50$ cells $/ \mathrm{ml})$ were spiked into healthy donor blood samples and flowed through the chip. The main factor affecting cell capture efficiency was blood sample flowrate, and capture efficiency decreased with increasing flowrate (Figure 1A). The highest capture efficiency was achieved at $0.5 \mathrm{ml} / \mathrm{h}(86.2 \pm 6.3 \%)$. To test the chip's capture efficiency at ultralow concentrations of cancer cells, $<10$ SKOV3ip1 cells were spiked into 1 $\mathrm{ml}$ of $1 \%$ bovine serum albumin (BSA) in $1 \times$ phosphatebuffered saline (PBS). We found that the chip's average capture efficiency was $55.7 \pm 23.2 \%(n=7)$ (Figure 1B). These results demonstrated that the microfluidic chip efficiently captured cancer cells even at low numbers.

\section{Patient characteristics}

Of the 61 enrolled patients, 30 (49\%) were diagnosed with ovarian cancer, 25 (41\%) had benign diseases, and the remaining $6(10 \%)$ had other malignant diseases. In the ovarian cancer group, 19 patients were diagnosed with high-grade serous ovarian carcinoma, five with ovarian clear cell carcinoma, two with low-grade serous ovarian carcinoma, two with endometrioid carcinoma, one with immature teratoma, and one with ovarian adult granulosa cell tumor (Supplementary Figure 1). In the benign group, eight patients were diagnosed with serous cystadenoma, four with mucinous cystadenoma, three with Brenner tumor, three with mature teratoma, two with borderline serous cystadenoma, two with borderline mucinous cystadenoma, two with fibroma, and one with ovarian simple cyst (Supplementary Table 2). In the "other malignant" group, two patients were diagnosed with Krukenberg tumor, one with retroperitoneal tumor, one with rectal metastatic carcinoma, one with colon metastatic carcinoma, and one with breast metastatic carcinoma (Supplementary Table 3). Patients diagnosed with ovarian cancer were older than those in the benign group, but patient weights, heights, and body mass indexes (BMI) did not differ significantly between groups (Supplementary Table 4).

Most ovarian cancer patients (53.3\%) were diagnosed at International Federation of Gynecology and Obstetrics (FigureO, 2013) Stage III (Table 2). Of all patients who received cytoreductive surgery, two-thirds did not have macroscopic residual disease or lymph node involvement.

\section{Patient baseline CTC counts}

We used the following immunofluorescent staining regimes: (DAPI+/E\&M+/CD45-/HE4+), (DAPI+/E\&M-/ CD45-/HE4+), and (DAPI+/E\&M+/CD45-/HE4-), to identify the three CTC types, which are referred to hereafter as $A, B$, and $C$ cells, respectively (Figure 2A). Table 2 lists the mean CTC subtype counts for each patient group. The marker, DAPI+/E\&M+/CD45-/HE4+, for identifying $A$ cells appeared to be the most effective in immunofluorescent detection of ovarian cancer CTCs. The number of $A$ cells in ovarian cancer patients was higher than that in the benign $(p=0.016)$ and "other malignant" groups $(p=0.047)$ (Figure 2B). However, CTC counts did not differ among the tumor subtypes across the three groups (Supplementary Table 1-3). Therefore, we considered combinations of two CTC types. Only numbers of $A+B$ cells combined 
Table 1: Detection and prognostic relevance of CTCs in ovarian cancer

\begin{tabular}{|c|c|c|c|c|c|c|c|c|}
\hline Authors (year) & $\begin{array}{l}\text { Study } \\
\text { Type }\end{array}$ & $\begin{array}{c}\text { No. of } \\
\text { Patients }\end{array}$ & Timing & Capture Method & $\begin{array}{c}\text { Detection } \\
\text { Method }\end{array}$ & $\begin{array}{c}\text { Targeted } \\
\text { Antigen/Gene }\end{array}$ & $\begin{array}{c}\text { Positive } \\
\text { Rate (\%) }\end{array}$ & $\begin{array}{l}\text { Prognostic } \\
\text { Significance }\end{array}$ \\
\hline $\begin{array}{l}\text { Marth et al. } \\
(2002)[20]\end{array}$ & $\begin{array}{l}\text { Case } \\
\text { Series }\end{array}$ & 90 & $\begin{array}{l}\text { Before adjuvant } \\
\text { chemotherapy }\end{array}$ & $\begin{array}{l}\text { Immunomagnetic } \\
\text { (Dynabeads } ®)\end{array}$ & ICC & MOC-31 & 12.0 & NS \\
\hline $\begin{array}{l}\text { Kurata et al. } \\
(2002)[21]\end{array}$ & $\begin{array}{l}\text { Case } \\
\text { Series }\end{array}$ & 24 & Not mentioned & Not separated & RT-PCR & CK7, CK20 & 46 & $\begin{array}{c}\text { Not } \\
\text { mentioned }\end{array}$ \\
\hline $\begin{array}{l}\text { Sapi et al. } \\
(2002) \text { [23] }\end{array}$ & $\begin{array}{l}\text { Case } \\
\text { Series }\end{array}$ & 28 & $\begin{array}{c}\text { Before any } \\
\text { therapy }\end{array}$ & Immunomagnetic & $\mathrm{ICC}$ & HEA-125, CD45 & 75 & NS \\
\hline $\begin{array}{l}\text { Judson et al. } \\
(2003)[24]\end{array}$ & $\begin{array}{l}\text { Case } \\
\text { Series }\end{array}$ & 59 & Before surgery & $\begin{array}{c}\text { Immunomagnetic } \\
\text { beads }\end{array}$ & $\mathrm{ICC}$ & $\begin{array}{l}\text { CK8 and 18, } \\
\text { TFS-2, CK7, } \\
\text { CK20, EGFR }\end{array}$ & 18.7 & NS \\
\hline $\begin{array}{l}\text { Oikonomopoulou } \\
\text { et al. (2006) [25] }\end{array}$ & $\begin{array}{l}\text { Case } \\
\text { Series }\end{array}$ & 24 & $\begin{array}{l}\text { Before and } \\
\text { after therapy }\end{array}$ & $\begin{array}{c}\text { Immunomagnetic } \\
\text { separation }\end{array}$ & RT-PCR & $\begin{array}{c}\text { Kallikreins, } \\
\text { BER-EP4 }\end{array}$ & 75 & NS \\
\hline $\begin{array}{l}\text { Wimberger et al. } \\
\text { (2007) [26] }\end{array}$ & $\begin{array}{l}\text { Case } \\
\text { Series }\end{array}$ & 57 & $\begin{array}{c}57 \text { before } \\
\text { therapy \& } 45 \\
\text { after therapy }\end{array}$ & Density gradient & $\mathrm{ICC}$ & $\begin{array}{l}\text { A45-B/B3, } \\
\text { CK8, 18, } 19\end{array}$ & 21 & NS \\
\hline $\begin{array}{l}\text { He et al. } \\
(2008) \text { [22] }\end{array}$ & $\begin{array}{l}\text { Case } \\
\text { Series }\end{array}$ & 20 & Not mentioned & Density gradient & $\begin{array}{c}\text { Flow } \\
\text { cytometry }\end{array}$ & $\begin{array}{l}\text { Folate- } \\
\text { AlexaFluor } 488 \\
\text { \& DUPA-FITC }\end{array}$ & 90 & NS \\
\hline $\begin{array}{l}\text { Fan et al. } \\
(2009)[6]\end{array}$ & $\begin{array}{l}\text { Case } \\
\text { Series }\end{array}$ & 66 & Before surgery & $\begin{array}{c}\mathrm{CAM}+\text { functional } \\
\text { enrichment }\end{array}$ & $\mathrm{ICC}$ & $\begin{array}{c}\text { EpCAM; CK 4, } \\
5,6,8,10,13 \\
\text { and } 18\end{array}$ & 60.6 & NS \\
\hline $\begin{array}{l}\text { Behbakht et al. } \\
\text { (2011) [27] }\end{array}$ & $\begin{array}{l}\text { Phase II } \\
\text { Clinical }\end{array}$ & 54 & $\begin{array}{c}\text { Before } \\
\text { and after } \\
\text { Temsirolimus }\end{array}$ & $\begin{array}{c}\text { Immunomagnetic } \\
\text { (CellSearch) }\end{array}$ & $\begin{array}{c}\text { ICC } \\
\text { (CellSearch) }\end{array}$ & EpCAM & $\begin{array}{c}44.0 \\
\text { (bef cycle 1) }\end{array}$ & NS \\
\hline $\begin{array}{l}\text { Poveda et al. } \\
(2011)[11]\end{array}$ & $\begin{array}{c}\text { Phase III } \\
\text { Clinical }\end{array}$ & 216 & $\begin{array}{l}\text { Before } 2 \text { nd line } \\
\text { chemotherapy }\end{array}$ & $\begin{array}{c}\text { Immunomagnetic } \\
\text { (CellSearch) }\end{array}$ & $\begin{array}{c}\text { ICC } \\
\text { (CellSearch) }\end{array}$ & $\begin{array}{c}\text { EpCAM; CK8, } \\
18 \text { and } 19\end{array}$ & 14.4 & NS \\
\hline $\begin{array}{l}\text { Aktas et al. } \\
(2011) \text { [7] }\end{array}$ & $\begin{array}{l}\text { Case } \\
\text { Series }\end{array}$ & 122 & $\begin{array}{c}\text { Before surgery } \\
\text { and/or after } \\
\text { chemotherapy }\end{array}$ & $\begin{array}{l}\text { Immunomagnetic } \\
\text { (Adnatest) }\end{array}$ & $\begin{array}{c}\text { RT-PCR } \\
\text { (Adnatest) }\end{array}$ & $\begin{array}{c}\text { EpCAM, MUC- } \\
\text { 1, CA-125 } \\
\text { HER-2 }\end{array}$ & $\begin{array}{c}19.0 \text { (bef } \\
\text { surgery) } \\
27.0 \text { (after } \\
\text { CT) }\end{array}$ & $\begin{array}{c}\mathrm{HR}=4.56 \\
(1.94-10.73) \\
p=0.05\end{array}$ \\
\hline $\begin{array}{l}\text { Liu et al. } \\
(2013) \text { [28] }\end{array}$ & $\begin{array}{l}\text { Case } \\
\text { Series }\end{array}$ & $\begin{array}{c}30 \text { new } \\
48 \\
\text { recurrent }\end{array}$ & $\begin{array}{c}\text { Before } \\
\text { chemotherapy }\end{array}$ & $\begin{array}{l}\text { Immunomagnetic } \\
\text { (CellSearch) }\end{array}$ & $\begin{array}{c}\text { ICC } \\
\text { (CellSearch) }\end{array}$ & EpCAM & $\begin{array}{c}60.0 \text { new } \\
53.8 \text { recurrent }\end{array}$ & NS \\
\hline $\begin{array}{l}\text { Obermayr et al. } \\
\text { (2013) [17] }\end{array}$ & $\begin{array}{l}\text { Case } \\
\text { Series }\end{array}$ & 216 & $\begin{array}{c}\text { Before } \\
\text { surgery \& } \\
\text { after adjuvant } \\
\text { chemotherapy }\end{array}$ & $\begin{array}{l}\text { Density gradient } \\
\text { centrifugation } \\
\text { RNA extraction } \\
\text { (Qiacube system) }\end{array}$ & RT-PCR & $\begin{array}{c}\text { PPIC, GPX8, } \\
\text { CDH3, TUSC3, } \\
\text { COL3A1, } \\
\text { LAMB1, MAM, } \\
\text { ESRP2, AGR2, } \\
\text { BAIAP2L1, } \\
\text { TFF1, EpCAM }\end{array}$ & $\begin{array}{c}24.5 \text { (bef } \\
\text { surgery) } \\
20.4 \text { (after } \\
\text { CT) }\end{array}$ & $\begin{array}{l}\mathrm{HR}=2.3 \\
(1.1-4.8) \\
p=0.024\end{array}$ \\
\hline $\begin{array}{l}\text { Pearl et al. } \\
(2014)[4]\end{array}$ & $\begin{array}{l}\text { Case } \\
\text { Series }\end{array}$ & 88 & Before surgery & $\begin{array}{c}\text { CAM } \\
\text { (functional } \\
\text { enrichment) }\end{array}$ & ICC & $\begin{array}{c}\text { EpCAM, CA- } \\
125, \\
\text { DPP4 \& CKs }\end{array}$ & 88.6 & $\begin{array}{l}\mathrm{HR}=1.06 \\
(0.41-2.73) \\
p=0.0219\end{array}$ \\
\hline $\begin{array}{l}\text { Kuhlmann et al. } \\
\text { (2014) [12] }\end{array}$ & $\begin{array}{l}\text { Case } \\
\text { Series }\end{array}$ & 143 & Before surgery & $\begin{array}{l}\text { Immunomagnetic } \\
\text { (Adnatest) }\end{array}$ & $\begin{array}{c}\text { RT-PCR } \\
\text { (Adnatest) }\end{array}$ & $\begin{array}{l}\text { EpCAM, MUC1, } \\
\text { MUC6, ERCC1 }\end{array}$ & 14.0 & $\begin{array}{c}\mathrm{HR}=1.85 \\
(1.03-3.32) \\
p=0.041\end{array}$ \\
\hline $\begin{array}{l}\text { Ning N et al. } \\
(2014)[16]\end{array}$ & $\begin{array}{l}\text { Case } \\
\text { Series }\end{array}$ & 141 & $\begin{array}{l}\text { Before and } \\
7 \text { th day after } \\
\text { surgery }\end{array}$ & $\begin{array}{c}\text { Immunomagnetic } \\
\text { beads-CD45 }\end{array}$ & $\begin{array}{c}\text { FISH } \\
\text { (centromere } \\
\text { probe 8) ICC }\end{array}$ & CD45, CK & 76.2 & $\begin{array}{c}\text { Not } \\
\text { mentioned }\end{array}$ \\
\hline $\begin{array}{l}\text { Kolostova et al. } \\
(2015) \text { [29] }\end{array}$ & $\begin{array}{l}\text { Case } \\
\text { Series }\end{array}$ & 118 & Before surgery & MetaCell & CM/RT-PCR & $\begin{array}{c}\text { MUC1, EpCAM, } \\
\text { CA125 }\end{array}$ & 65.2 & NS \\
\hline $\begin{array}{l}\text { Kolostova et al. } \\
(2016)[30]\end{array}$ & $\begin{array}{l}\text { Case } \\
\text { Series }\end{array}$ & 56 & Before surgery & MetaCell & $\mathrm{ICC}$ & - & 58 & $\begin{array}{c}\text { Not } \\
\text { mentioned }\end{array}$ \\
\hline This article & $\begin{array}{l}\text { Case } \\
\text { Series }\end{array}$ & $\begin{array}{c}30 \\
\text { patients } \\
31 \\
\text { controls }\end{array}$ & Before surgery & $\begin{array}{l}\text { Size-based } \\
\text { microfluidic } \\
\text { separation }\end{array}$ & $\mathrm{ICC}$ & $\begin{array}{c}\text { EpCAM, panCK, } \\
\text { CK7, Vimentin } \\
\text { and HE4 }\end{array}$ & 73.3 & \\
\hline
\end{tabular}

NS: No Significance. 
(DAPI+/CD45-/HE4+ cells) differed between groups ( $p=0.020$, Figure 2C), while the other two combinations considered $(A+C$ cells, DAPI+/E\&M+/CD45-; and $A+$ $B+C$ cells, DAPI+/CD45-) did not differ $(p>0.05$, data not shown). Thus, the $A$ cell phenotype (DAPI+/E\&M+/ CD45-/HE4+) could be used to best describe ovarian cancer CTCs. Additionally, all three CTC types were detected in patients with normal and elevated CA125 levels, although their numbers did not differ significantly $(A: p=0.966, B$ : $p=0.635, C: p=0.724$; Table 3).

\section{CTCs vs. serum CA125 for screening patients at high risk of ovarian cancer}

To compare the diagnostic efficiencies of CTC counts and serum CA125, receiver operating characteristic (ROC) curves were plotted using the benign and "other malignant" groups as the control group (Figure $3 \mathrm{~A}$ ). Taking $A$ cells (DAPI+/E\&M+/CD45-/HE4+) as the CTCdefining phenotype, we identified cutoff points of $\geq 0.5 / \mathrm{mL}$ for CTCs and $\geq 98.55 \mathrm{U} / \mathrm{mL}$ for CA125 (Table 3A). The area under curve (AUC) for CTCs was larger than that for CA125 (Table 3A). Although specificity was lower for CTCs than CA125, CTC sensitivity was much higher than that of CA125. Subsequently, we considered CTCs and CA125 combined in screening ovarian cancer patients. We analyzed ROC curves for all CTC types detected in CA125 normal $(\leq 35 \mathrm{U} / \mathrm{ml})$ and CA125 elevated $(>35 \mathrm{U} / \mathrm{ml})$ patients (Figure $3 \mathrm{~B}$ and $3 \mathrm{C}$ ). CTC counts were the same in ovarian cancer cohorts and control cohorts with normal CA125 levels $(p>0.05$; Table 3B). However, CTC count was an indicator for ovarian cancer in CA125 elevated patients $(p=0.007$ for $A$ cells, Table 3C). Specificity was relatively high (0.867), suggesting that CTC count could be a secondary exclusion criterion in patients with elevated serum CA125.

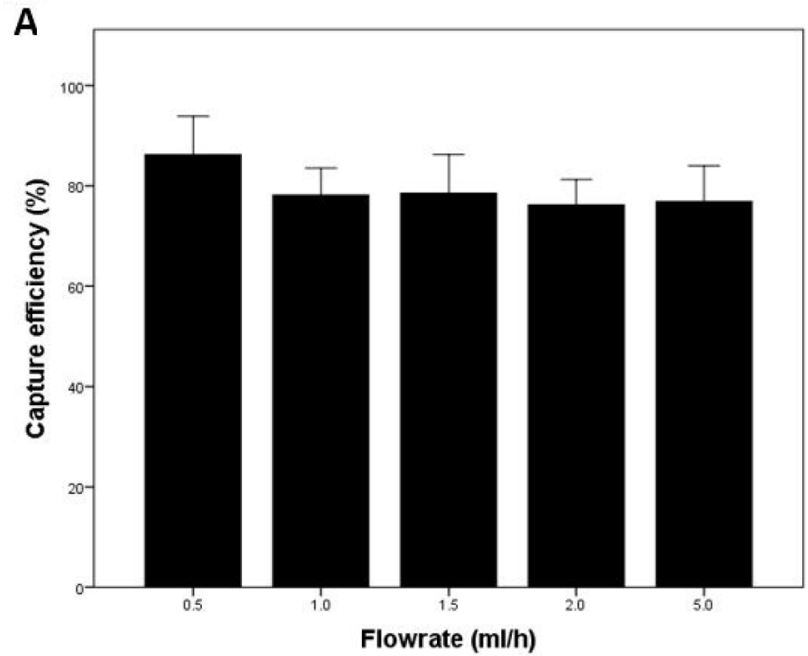

\section{CTC count was an independent predictor of ovarian cancer}

We examined CTC count as an independent indicator of ovarian cancer using Pearson's chi-squared test (Table 4). Pearson correlation coefficients for CTC count and other clinicopathological characteristics showed no direct correlations between them, indicating that CTC count could be an independent criterion. However, there was a correlation between ascites and elevated CA125 values ( $p=0.016$; Table 4).

\section{HE4+ CTCs were heterogeneous in ovarian cancer patient peripheral blood}

We performed immunohistochemical (IHC) staining for HE4 in all patients with ovarian cancer. Surprisingly, CTC count in HE4 IHC positive patients was similar to that in HE4 IHC negative patients ( $p=0.781$; Figure 4A). We then assessed CTC counts and paired IHC results for each patient with ovarian cancer. In most HE4 IHC positive patients, HE4+ CTCs were detected in peripheral blood, but in some of these patients, we could only identify DAPI+/E\&M+/CD45-/HE4- cells (possibly circulating endothelial cells) (Figure 4B). HE4+ CTCs were also detected in the peripheral blood of HE4 IHC negative patients (Figure 4B), indicating that peripheral HE4+ CTC count might be independent of HE4 expression in the primary carcinoma, and that CTC surface markers might differ compared to the primary site.

\section{DISCUSSION}

Liquid biopsies, including CTC, ctDNA, and exosome assessments, have been considered to be useful methods of monitoring treatment response, assessing the

B

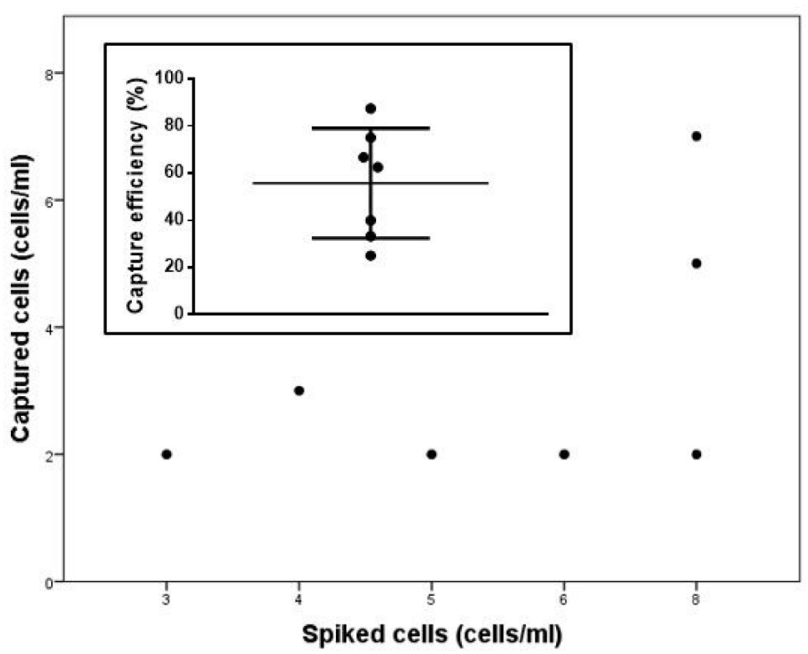

Figure 1: Chip characterization. (A) Chip capture efficiency at various flowrates ( $n=3$ per flowrate). SKOV3ip1 cells (50 cells/ml) were spiked into healthy donor blood samples. (B) Number of cells captured in the chip vs. number of cells spiked into the buffer solution. Inset: Chip capture efficiency using buffer solution spiked with very low numbers of cells $(n=7)$. 
emergence of drug resistance, and quantifying minimal residual disease [35]. Additionally, a new metastasis stage, cM0 (i+), has been added between the traditional M0 and M1 stages for breast and lung cancer as a result of liquid biopsy results by the American Joint Committee on Cancer (AJCC) [36]. The National Comprehensive Cancer Network (NCCN) also incorporates liquid biopsies in their new non-small cell lung cancer guideline [14], and suggests that liquid biopsies should be considered when tissue biopsy is not feasible.

However, much work is still needed to establish CTC detection as a reliable biomarker in ovarian cancer. While CTCs can be detected in ovarian cancer patients, detection rates vary greatly (Table 1), possibly due to patient heterogeneity and the variety of detection methods.
The prognostic value of CTCs in ovarian cancer is still in question, as some studies failed to draw significant conclusions.

Epithelial ovarian cancer metastasis is thought to occur at very late stages via direct surface spread [37], and it appears that CTC detection is not useful for early monitoring. A recent study based on the parabiosis model, in which paired mice shared blood but not lymphatic vessels, highlighted hematogenous metastasis as an important mode of ovarian cancer metastasis [10]. Their results also demonstrated a preference for metastasis to the omentum via the hematogenous route, supporting the diagnostic potential of CTCs in patients with suspicious abdominal masses. Thus, accurate capture of CTCs based on size and other biophysical properties, or using markers
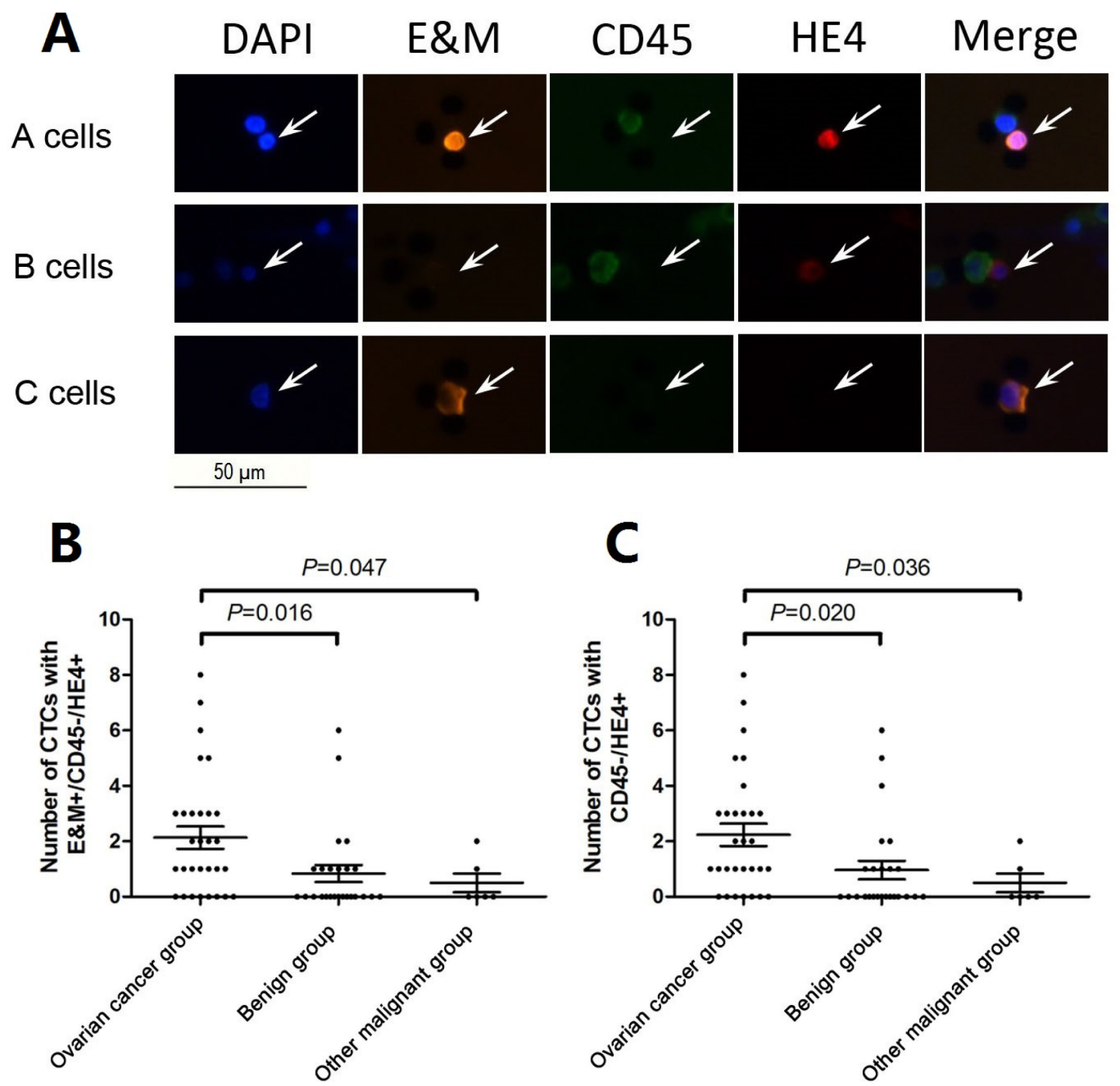

Figure 2: Representative images for three CTC types captured from peripheral blood of patients with suspicious abdominal masses. (A) Top row: A cells with DAPI+/E\&M+/CD45-/HE4+; middle row: $B$ cells with DAPI+/E\&M-/CD45-/HE4+ and bottom row: $C$ cells with DAPI+/E\&M+/CD45-/HE4-. (B) The number of $A$ cells with DAPI+/E\&M+/CD45-/HE4+ was higher in the ovarian cancer group than the benign $(p=0.016)$ and "other malignant" groups $(p=0.047)$. (C) The number of $A+B$ cells with DAPI + / CD45-/HE4+ was higher in the ovarian cancer group than the benign $(p=0.020)$ and "other malignant" groups $(p=0.036)$. 
Table 2: Baseline characteristics of enrolled patients

\begin{tabular}{|c|c|c|c|c|}
\hline \multirow[b]{2}{*}{ Total } & $\begin{array}{c}\text { No. of patients } \\
(\%)\end{array}$ & \multicolumn{3}{|c|}{ Captured CTC/mL } \\
\hline & $61(100)$ & $\begin{array}{c}\text { A cells } \\
\text { (DAPI+/E\&M+/ } \\
\text { CD45-/HE4+) }\end{array}$ & $\begin{array}{c}\text { B cells } \\
\text { (DAPI+/E\&M-/ } \\
\text { CD45-/HE4+) }\end{array}$ & $\begin{array}{c}\text { C cells } \\
\text { (DAPI+/E\&M+/ } \\
\text { CD45-/HE4-) }\end{array}$ \\
\hline \multicolumn{2}{|c|}{ Tumor stage (Kruskal-Wallis test) } & $p=0.064$ & $p=0.105$ & $p=0.742$ \\
\hline Benign & $25(41.0)$ & $0.8 \pm 1.5(0-6)$ & $0.1 \pm 0.6(0-3)$ & $2.7 \pm 6.6(0-31)$ \\
\hline Stage I & $8(13.2)$ & $2.1 \pm 1.8(0-6)$ & $0.0 \pm 0.0(0-0)$ & $2.5 \pm 3.4(0-8)$ \\
\hline Stage II & $4(6.6)$ & $2.0 \pm 2.1(0-5)$ & $0.3 \pm 0.5(0-1)$ & $2.0 \pm 2.4(0-5)$ \\
\hline Stage III & $16(26.4)$ & $2.3 \pm 2.5(0-8)$ & $0.06 \pm 0.3(0-1)$ & $2.3 \pm 4.2(0-15)$ \\
\hline Stage IV & $2(3.3)$ & $1.0 \pm 1.4(0-2)$ & $0.5 \pm 0.71(0-1)$ & $0.0 \pm 0.0(0)$ \\
\hline Other malignant diseases & $6(9.8)$ & $0.5 \pm 0.8(0-2)$ & $0.0 \pm 0.0(0-0)$ & $2.8 \pm 4.2(0-11)$ \\
\hline $\begin{array}{l}\text { Macroscopic residual } \\
\text { disease }^{*}(t \text {-test })\end{array}$ & & $p=0.741$ & $p=0.364$ & $p=0.776$ \\
\hline Yes & $10(34.5)$ & $2.2 \pm 2.3(0-8)$ & $0.1 \pm 0.3(0-1)$ & $2.4 \pm 3.2(0-10)$ \\
\hline No & $19(65.5)$ & $2.1 \pm 2.2(0-7)$ & $0.1 \pm 0.2(0-1)$ & $2.2 \pm 3.9(0-15)$ \\
\hline $\begin{array}{l}\text { Lymph node involvement } \\
\text { (ANOVA) }\end{array}$ & & $p=0.53$ & $p<0.001$ & $p=0.117$ \\
\hline Yes & $7(23.3)$ & $3.0 \pm 2.5(0-7)$ & $0.1 \pm 0.4(0-1)$ & $3.0 \pm 5.4(0-15)$ \\
\hline No & $17(56.7)$ & $2.1 \pm 2.3(0-8)$ & $0.0 \pm 0.0(0)$ & $2.4 \pm 3.3(0-10)$ \\
\hline Unmeasured $\dagger$ & $6(20)$ & $1.3 \pm 1.2(0-3)$ & $0.3 \pm 0.5(0-1)$ & $0.5 \pm 1.2(0-3)$ \\
\hline CA-125 (t-test) & & $p=0.966$ & $p=0.635$ & $p=0.724$ \\
\hline$\leq 35 \mathrm{U} / \mathrm{mL}$ & $21(36.7)$ & $1.5 \pm 2.2(0-8)$ & $0.1 \pm 0.7(0)$ & $1.7 \pm 3.4(0-15)$ \\
\hline$>35 \mathrm{U} / \mathrm{mL}$ & $36(63.3)$ & $1.5 \pm 1.9(0-7)$ & $0.1 \pm 0.3(0-1)$ & $2.1 \pm 3.5(0-10)$ \\
\hline
\end{tabular}

*Benign samples were not included for these characteristics.

Did not undergo the surgery or lymph node dissection.

Table 3: Statistic results of the ROC curve analysis

\begin{tabular}{|c|c|c|c|c|c|}
\hline & Cutoff point & Area under curve & Sensitivity & Specificity & $p$-value \\
\hline \multicolumn{6}{|l|}{ A: In all patients } \\
\hline A cell & 0.5 & 0.716 & 0.733 & 0.630 & 0.005 \\
\hline B cell & 0.5 & 0.530 & 0.100 & 0.963 & 0.701 \\
\hline $\mathrm{C}$ cell & 2.5 & 0.538 & 0.300 & 0.852 & 0.620 \\
\hline $\mathrm{A}+\mathrm{B}$ cell & 0.5 & 0.715 & 0.767 & 0.630 & 0.005 \\
\hline$A+C$ cell & 2.5 & 0.661 & 0.533 & 0.741 & 0.037 \\
\hline $\mathrm{A}+\mathrm{B}+\mathrm{C}$ cell & 3.5 & 0.534 & 0.300 & 0.889 & 0.660 \\
\hline CA125 & 98.55 & 0.691 & 0.567 & 0.815 & 0.013 \\
\hline \multicolumn{6}{|c|}{ B: In CA125 normal patients $\dagger$} \\
\hline A cell & 0.5 & 0.653 & 0.778 & 0.583 & 0.241 \\
\hline B cell & 0.5 & 0.458 & 0.000 & 1.000 & 0.749 \\
\hline $\mathrm{C}$ cell & 3.5 & 0.551 & 0.333 & 0.917 & 0.696 \\
\hline $\mathrm{A}+\mathrm{B}$ cell & 0.5 & 0.616 & 0.778 & 0.583 & 0.374 \\
\hline$A+C$ cell & 11 & 0.583 & 0.222 & 1.000 & 0.522 \\
\hline
\end{tabular}




\begin{tabular}{lrllll} 
A + B + C cell & 3.5 & 0.519 & 0.333 & 0.917 & 0.887 \\
\hline C: In CA125 elevated patients $\dagger$ & & & & \\
\hline A cell & 1.5 & 0.767 & 0.571 & 0.867 & 0.007 \\
B cell & 0.5 & 0.571 & 0.143 & 1.000 & 0.470 \\
C cell & 2.5 & 0.517 & 0.286 & 0.867 & 0.860 \\
A + B cell & 2.5 & 0.790 & 0.476 & 1.000 & 0.003 \\
A + C cell & 2.5 & 0.689 & 0.619 & 0.733 & 0.056 \\
A + B + C cell & 3.0 & 0.533 & 0.286 & 0.867 & 0.736 \\
\hline
\end{tabular}

$A$ cell: DAPI+/E\&M+/CD45-/HE4+ cells; $B$ cell: DAPI+/E\&M-/CD45-/HE4+ cells; $C$ cell: DAPI+/E\&M+/CD45-/HE4cells; $A+B$ cell: DAPI+/CD45-/HE4+ cells; $A+C$ cell: DAPI+/E\&M+/CD45- cells; $A+B+C$ cell: DAPI+/CD45-cells. ${ }^{\dagger} \mathrm{CA} 125$ value was estimated as "normal" and "elevated" based on cutoff, $35 \mathrm{U} / \mathrm{mL}$;

commonly expressed on the surfaces of these cells [35], could greatly improve cancer detection. EpCAM and cytokeratins are the most widely used surface markers in CTC detection, but detection rates are limited for single markers used alone [27, 28]. Thus, identification methods using multiple markers are the best options for detecting CTCs in ovarian cancer patient peripheral blood.

Serum HE4 is a promising biomarker for discriminating between benign and malignant pelvic masses [38]. HE4 is secreted by cells and can also be detected in the cytoplasm of ovarian cancer cells [39], and may therefore be a useful marker for detecting ovarian cancer CTCs. We stained for HE4 and epithelial or mesenchymal markers (EpCAM, cytokeratins, and vimentin) and found that E\&M+/CD45-/HE4+ CTCs had diagnostic significance in patients with pelvic or abdominal masses. However, E\&M+/CD45-/HE4- cell numbers did not differ significantly between cancer and control cohorts, at least in part because normal circulating endothelial cells can also exhibit this phenotype. These results indicated that ovarian cancer CTCs express HE4 on the cell surface and that HE4 could be a detection marker for ovarian cancer CTCs.

We also observed that CTC detection results (positive rates) did not exactly match HE4 IHC results in ovarian cancer patients; some HE4 IHC positive patients had negative CTCs, while some HE4 IHC negative patients had positive CTCs. This could be attributed to tumor heterogeneity $[9,35]$, in that HE4 may not be equably expressed in tumors and CTCs, leading to detection discrepancies between IHC results and CTC counts. Importantly, our study only shows the diagnostic utility of HE4+ CTCs in patients at high risk for ovarian cancer, and we did not attempt to develop a screening test for the general population. While the diagnostic and prognostic utility of CTCs in the general population must be assessed through larger prospective studies, our results support the use of DAPI+/E\&M+/CD45-/HE4+ CTC counts for diagnosing ovarian cancer in patients with suspicious pelvic or abdominal masses.
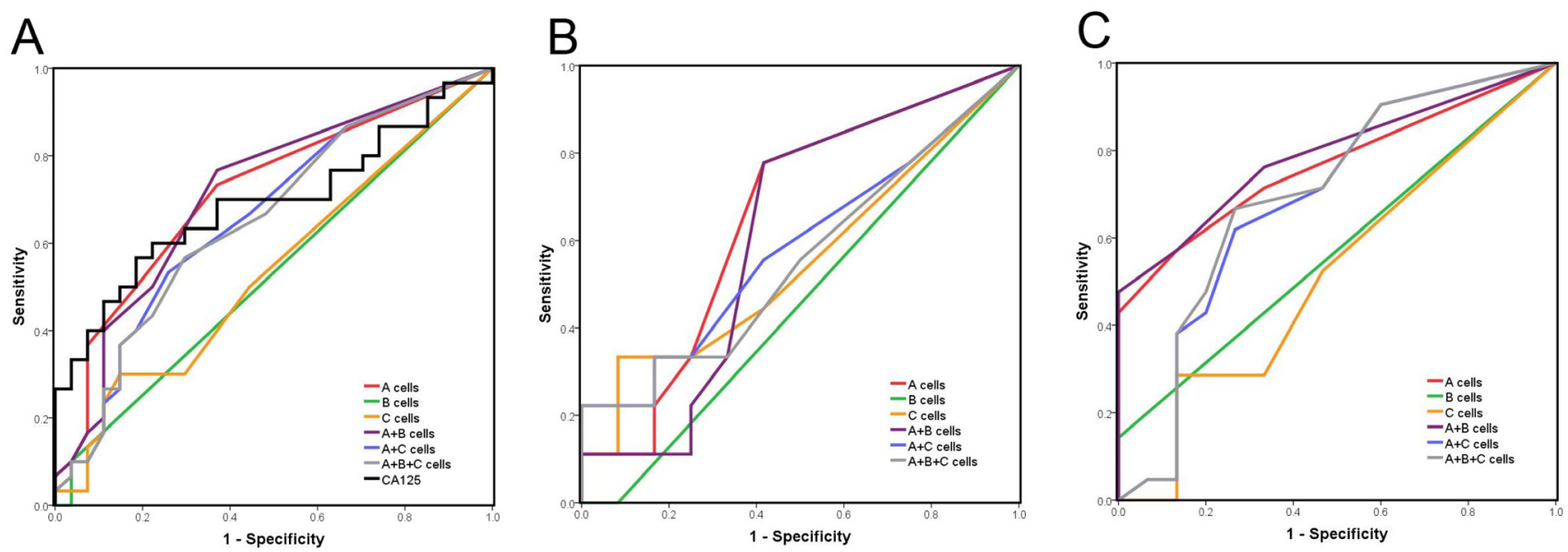

Figure 3: ROC curve analysis in different subgroups. (A) In total enrolled patients, (B) In CA125 normal patients, (C) In CA125 elevated patients. Benign and other malignant patients were considered as the control group, cutoff value of CA125 was considered as $35 \mathrm{U} / \mathrm{ml}$. 
Table 4: Correlation analysis of CTCs and other clinicopathological characteristics

\begin{tabular}{lcccccc}
\hline Pearson correlation test & CTC count $^{*}$ & Lymph node & $\begin{array}{c}\text { Peritoneal } \\
\text { Metastasis }\end{array}$ & Ascites & $\begin{array}{c}\text { Residual } \\
\text { disease }\end{array}$ & CA125 $^{\dagger}$ \\
\hline CTC count* & & 0.795 & 0.269 & 0.745 & 0.507 & 0.719 \\
Lymph node & 0.795 & & 0.604 & 0.382 & 0.967 & 0.204 \\
Peritoneal Metastasis & 0.269 & 0.604 & & 0.395 & 0.007 & 0.157 \\
Ascites & 0.745 & 0.382 & 0.395 & & 0.011 & 0.016 \\
Residual disease & 0.507 & 0.967 & 0.007 & 0.011 & 0.076 \\
CA125 $^{\dagger}$ & 0.719 & 0.204 & 0.157 & 0.016 & 0.076 \\
\hline
\end{tabular}

*A cell was used as the criteria for positive and its cutoff value was $0.5 / \mathrm{mL}$ as defined in Table 3 .

Cutoff value was defined as $35 \mathrm{U} / \mathrm{ml}$.
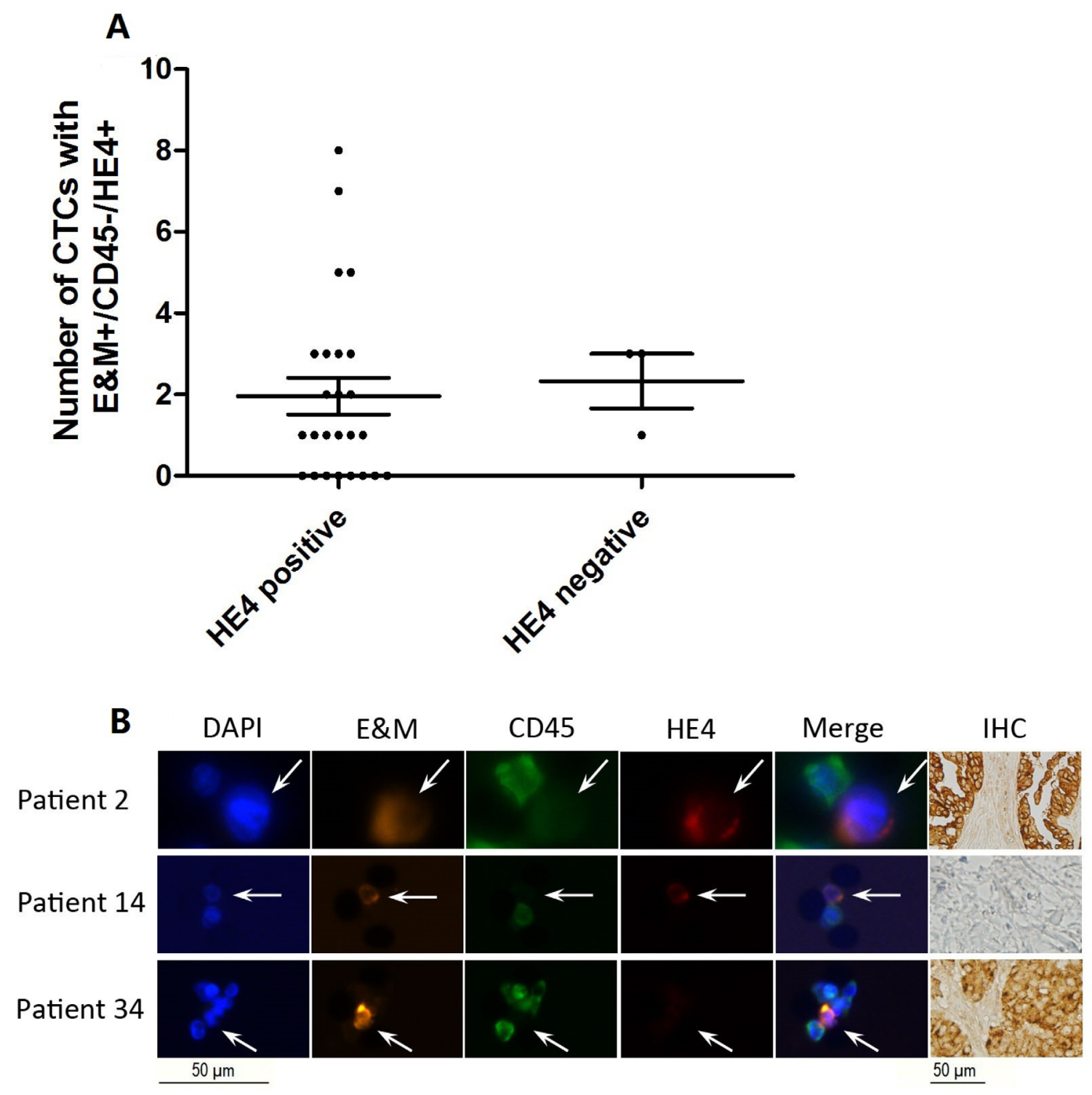

Figure 4: Correlation between HE4 expression in ovarian cancer tissues and peripheral blood CTC count. (A) There was not significant difference between the number of $A$ cells with DAPI+/E\&M+/CD45-/HE4+ in HE4 IHC positive patients and that in HE4 IHC negative patients. (B) Representative images of DAPI+/E\&M+/ CD45-/HE4+ CTCs and HE4+ tissues (top), DAPI+/E\&M+/ CD45-/HE4+ CTCs and HE4- tissues (middle), and DAPI+/E\&M+/CD45-/HE4- cells and HE4+ tissues (bottom). 


\section{MATERIALS AND METHODS}

\section{Patients and samples}

Sixty-one women admitted to Peking University People's Hospital between August 2016 and March 2017 and suspected of having ovarian carcinoma were enrolled in the study. Written informed consent was obtained from all patients in accordance with the Declaration of Helsinki. Suspicion of disease was based on clinical examination and ultrasound results. All patients underwent either abdominal or laparoscopic surgery followed by a histological diagnosis. Tumors were classification as IA to IV according to FigureO (2013). Patients receiving neoadjuvant chemotherapy before surgery were excluded. This study was approved by our Institutional Review Board.

Four milliliters of peripheral blood were obtained from each patient for the purpose of CTC detection prior to surgery. Blood samples were drawn in Vacuette EDTA tubes (BD Medical Tech., USA) and centrifuged at $500 \mathrm{~g}$ for $5 \mathrm{~min}$ at room temperature. Supernatant (plasma) was removed and the remaining blood fraction was processed using a microfluidic device within $4 \mathrm{~h}$.

\section{Microfluidic chip design and fabrication}

The microfluidic chip was adapted from our previous studies on circulating endothelial cells in coronary artery disease patients with angina pectoris [40]. It consisted of eight capture chambers, each $3700 \mu \mathrm{m}$ (length) $\times 1036$ $\mu \mathrm{m}$ (width) $\times 25 \mu \mathrm{m}$ (height). Each chamber had $\sim 700$ capture sites of three different sizes, 8,10 , and $15 \mu \mathrm{m}$, to allow smaller erythrocytes and most leukocytes to pass through while retaining larger CTCs. The device had two inlets and one outlet, all equipped with pre-filters $(60 \mu \mathrm{m})$ to prevent clogging by large debris. One inlet served as the blood sample inlet while the other served as the inlet for reagents needed to perform on-chip immunofluorescence staining. The device was designed using AutoCAD software (Autodesk, USA). We worked with CapitalBio Beijing to fabricate the master mold via photolithography. Briefly, the device pattern was printed on photo film. An 8 -inch silicon wafer was spin-coated with a $25 \mu \mathrm{m}$-thick layer of SU-8 photoresist (Microchem, USA). The photo film was placed on top of the photoresist and was exposed to UV, followed by post-exposure baking and development to produce a master mold. The microfluidic device was then produced using soft lithography. A 9:1 (weight) mixture of polydimethylsiloxane (PDMS) prepolymer and its crosslinker (Sylgard 184, Dow Corning, USA) was poured onto the master mold and degassed in the vacuum dessicator for $30 \mathrm{~min}$. The PDMS mixture was cured in the oven at $60^{\circ} \mathrm{C}$ for $4 \mathrm{~h}$. Cured PDMS was then peeled from the master. Holes were punched at designated inlet and outlet ports on the PDMS using a 0.75-mm-diameter puncher (Harris Uni-core, Sigma-Aldrich, USA). The
PDMS and a glass slide were cleaned with a piece of Scotch tape, and then oxygen plasma-treated and bonded together. To reinforce bonding, the PDMS device was baked in the oven at $60^{\circ} \mathrm{C}$ for $20 \mathrm{~min}$.

\section{Determining chip capture efficiency using a cancer cell line}

SKOV3ip1 ovarian cancer cells were cultured in RPMI-1640 media supplemented with 10\% FBS and 1\% penicillin/streptomycin/amphotericin at $37^{\circ} \mathrm{C}$ and $5 \%$ $\mathrm{CO}_{2}$. Before use, cells were stained with CellTracker Red CMTPX dye (Thermo Fisher Scientific, USA) for $30 \mathrm{~min}$ and then trypsinized with $0.25 \%$ trypsin-EDTA. The capture efficiency of the microfluidic chip was determined by flowing healthy donor blood samples spiked with stained SKOV3ip1 cells $(50$ cells $/ \mathrm{ml})$ through the chip at flowrates of $0.5,1.0,1.5,2.0$, and $5.0 \mathrm{ml} / \mathrm{h}(n=3$ per flowrate). Flowrate was controlled using a syringe pump (Longer Pump, China). Captured cells were counted under a microscope. Capture efficiency was evaluated as the percentage of captured cells over spiked cells. To test chip performance at ultralow concentrations of cancer cells, $<10$ cells were spiked into $1 \mathrm{ml}$ of $1 \%$ BSA in $1 \times$ PBS buffer. The spiked buffer solution flowed through the chip at $0.5 \mathrm{ml} / \mathrm{h}$. This test was repeated seven times with duplicates.

\section{Blood processing}

One $\mathrm{ml}$ of plasma-removed blood was diluted with $1 \mathrm{ml}$ of buffer solution (1\% BSA and $8 \mathrm{mM}$ EDTA in $1 \times$ PBS). Diluted blood was injected into the microfluidic chip using the syringe pump at $500 \mu \mathrm{l} / \mathrm{h}$. Larger CTCs were isolated by staggered capture sites with decreasing gap sizes $(15-8 \mu \mathrm{m})$. On-chip immunofluorescent staining was performed to allow easy cell visualization and enumeration. Briefly, captured cells (CTCs and some leukocytes) were fixed by perfusing $4 \%$ paraformaldehyde through the chip for $15 \mathrm{~min}$. Cells were then permeabilized with $0.1 \%$ Triton X-100 for 10 min, washed with $1 \times$ PBS for $20 \mathrm{~min}$, and blocked with 5\% BSA for at least 30 $\mathrm{min}$ at room temperature to avoid nonspecific binding of antibodies. A mixture of conjugated antibodies was used: CD45-Alexa Fluor 488 (Invitrogen, USA), EpCAMphycoerythrin (Abcam, UK), panCK-phycoerythrin (Abcam), vimentin-phycoerythrin (Abcam), CK7/17phycoerythrin (Novus Biologicals, USA), and HE4Alexa Fluor 647 (Abcam). DAPI (4',6-diamidino-2phenylindole; Thermo Fischer Scientific) was also added to the mixture for nuclear staining. Immunolabeled cells were washed with $1 \times$ PBS for at least $30 \mathrm{~min}$. Captured cells were imaged manually using LAS Core microscope imaging software (version 4.4; Leica Microsystems, Germany) and analyzed using ImageJ software (version 1.50i; National Institutes of Health, USA) and Adobe Photoshop CC 2015 software (Adobe Systems, USA). 


\section{ELISA}

CA125 was measured in duplicate in each patient serum sample using commercially available enzymelinked immunosorbent assay (ELISA) kits (E99202Hu, Uscn Life Science, USA) according to the manufacturer's instructions, with a Multiskan EX plate reader (Thermo Fisher Scientific).

\section{Immunohistochemistry}

IHC assessment of HE4 expression in patient tissues was performed as previously described [41].

\section{Statistical analysis}

Samples from benign tumors and other malignant diseases were established as the control group. Numerical data are presented as means \pm standard deviation (range). Two-tailed $t$-test was used to compare the number of CTCs and CA125 levels between two patient subgroups, and ANOVA was used when comparing more than two subgroups. The Mann-Whitney $U$ test was performed when sample sizes were insufficient for the $t$-test. ROC curves were used to assess the diagnostic efficiencies of CTC counts and CA125 level. Absolute CA125 levels were interpreted as normal $(0, \leq 35 \mathrm{U} / \mathrm{ml})$ or elevated $(1,>35 \mathrm{U} / \mathrm{ml})$ compared to so-called relative CA125 value. Pearson's chi-squared test was used to analyze correlations between CTC counts and other clinicopathological characteristics. All statistical analyses were performed using SPSS software (version 19, IBM, USA) and GraphPad Prism software (version 5, GraphPad Software, USA). $p<0.05$ was considered statistically significant.

\section{ACKNOWLEDGMENTS}

The authors are very grateful to all patients and healthy volunteers who took part in this study.

\section{CONFLICTS OF INTEREST}

The authors declare that they have no conflicts of interest.

\section{GRANT SUPPORT}

This work was financially supported by the National Key Research and Development Program of China (No. 2016YFA0201400).

\section{REFERENCES}

1. Siegel RL, Miller KD, Jemal A. Cancer Statistics, 2017. CA Cancer J Clin. 2017; 67:7-30.
2. Chen W, Zheng R, Baade PD, Zhang S, Zeng H, Bray F, Jemal A, Yu XQ, He J. Cancer statistics in China, 2015. CA Cancer J Clin. 2016; 66:115-132.

3. Goodman MT, Howe HL, Tung KH, Hotes J, Miller BA, Coughlin SS, Chen VW. Incidence of ovarian cancer by race and ethnicity in the United States, 1992-1997. Cancer. 2003; 97:2676-2685.

4. Pearl ML, Zhao Q, Yang J, Dong H, Tulley S, Zhang Q, Golightly M, Zucker S, Chen WT. Prognostic analysis of invasive circulating tumor cells (iCTCs) in epithelial ovarian cancer. Gynecol Oncol. 2014; 134:581-590.

5. Hacker NF, Rao A. Surgery for advanced epithelial ovarian cancer. Best Pract Res Clin Obstet Gynaecol. 2016.

6. Fan T, Zhao Q, Chen JJ, Chen WT, Pearl ML. Clinical significance of circulating tumor cells detected by an invasion assay in peripheral blood of patients with ovarian cancer. Gynecol Oncol. 2009; 112:185-191.

7. Aktas B, Kasimir-Bauer S, Heubner M, Kimmig R, Wimberger P. Molecular profiling and prognostic relevance of circulating tumor cells in the blood of ovarian cancer patients at primary diagnosis and after platinum-based chemotherapy. Int J Gynecol Cancer. 2011; 21:822-830.

8. Lengyel E. Ovarian cancer development and metastasis. Am J Pathol. 2010; 177:1053-1064.

9. Yeung TL, Leung CS, Yip KP, Au Yeung CL, Wong ST, Mok SC. Cellular and molecular processes in ovarian cancer metastasis. A Review in the Theme: Cell and Molecular Processes in Cancer Metastasis. Am J Physiol Cell Physiol. 2015; 309:C444-456.

10. Pradeep S, Kim SW, Wu SY, Nishimura M, ChaluvallyRaghavan P, Miyake T, Pecot CV, Kim SJ, Choi HJ, Bischoff FZ, Mayer JA, Huang L, Nick AM, et al. Hematogenous metastasis of ovarian cancer: rethinking mode of spread. Cancer cell. 2014; 26:77-91.

11. Poveda A, Kaye SB, McCormack R, Wang S, Parekh T, Ricci D, Lebedinsky CA, Tercero JC, Zintl P, Monk BJ. Circulating tumor cells predict progression free survival and overall survival in patients with relapsed/recurrent advanced ovarian cancer. Gynecol Oncol. 2011; 122:567-572.

12. Kuhlmann JD, Wimberger P, Bankfalvi A, Keller T, Scholer S, Aktas B, Buderath P, Hauch S, Otterbach F, Kimmig R, Kasimir-Bauer S. ERCC1-positive circulating tumor cells in the blood of ovarian cancer patients as a predictive biomarker for platinum resistance. Clin Chem. 2014; 60:1282-1289.

13. Pukazhendhi G, Gluck S. Circulating tumor cells in breast cancer. J Carcinog. 2014; 13:8.

14. Ettinger DS, Wood DE, Aisner DL, Akerley W, Bauman J, Chirieac LR, D'Amico TA, DeCamp MM, Dilling TJ, Dobelbower M, Doebele RC, Govindan R, Gubens MA, et al. Non-Small Cell Lung Cancer, Version 5.2017, NCCN Clinical Practice Guidelines in Oncology. J Natl Compr Canc Netw. 2017; 15:504-535. 
15. Msaouel P, Koutsilieris M. Diagnostic value of circulating tumor cell detection in bladder and urothelial cancer: systematic review and meta-analysis. BMC cancer. 2011; 11:336.

16. Ning N, Zhan T, Zhang $Y$, Chen Q, Feng F, Yang Z, Liu Z, Xu D, Wang F, Guo Y, Xing J, Guan Y, Cui W. Improvement of specific detection of circulating tumor cells using combined CD45 staining and fluorescence in situ hybridization. Clin Chim Acta. 2014; 433:69-75.

17. Obermayr E, Castillo-Tong DC, Pils D, Speiser P, Braicu I, Van Gorp T, Mahner S, Sehouli J, Vergote I, Zeillinger R. Molecular characterization of circulating tumor cells in patients with ovarian cancer improves their prognostic significance - a study of the OVCAD consortium. Gynecol Oncol. 2013; 128:15-21.

18. Kallergi G, Papadaki MA, Politaki E, Mavroudis D, Georgoulias V, Agelaki S. Epithelial to mesenchymal transition markers expressed in circulating tumour cells of early and metastatic breast cancer patients. Breast Cancer Res. 2011; 13:R59.

19. Hou HW, Warkiani ME, Khoo BL, Li ZR, Soo RA, Tan DS, Lim WT, Han J, Bhagat AA, Lim CT. Isolation and retrieval of circulating tumor cells using centrifugal forces. Sci Rep. 2013; 3:1259.

20. Marth C, Kisic J, Kaern J, Trope C, Fodstad O. Circulating tumor cells in the peripheral blood and bone marrow of patients with ovarian carcinoma do not predict prognosis. Cancer. 2002; 94:707-712.

21. Kurata H, Takakuwa K, Tsuneki I, Aoki Y, Tanaka K. Ovarian tumor cell detection in peripheral blood progenitor cells harvests by RT-PCR. Acta Obstet Gynecol Scand. 2002; 81:555-559.

22. He W, Kularatne SA, Kalli KR, Prendergast FG, Amato RJ, Klee GG, Hartmann LC, Low PS. Quantitation of circulating tumor cells in blood samples from ovarian and prostate cancer patients using tumor-specific fluorescent ligands. Int J Cancer. 2008; 123:1968-1973.

23. Sapi E, Okpokwasili NI, Rutherford T. Detection of telomerase-positive circulating epithelial cells in ovarian cancer patients. Cancer Detect Prev. 2002; 26:158-167.

24. Judson PL, Geller MA, Bliss RL, Boente MP, Downs LS Jr, Argenta PA, Carson LF. Preoperative detection of peripherally circulating cancer cells and its prognostic significance in ovarian cancer. Gynecol Oncol. 2003; 91:389-394.

25. Oikonomopoulou K, Scorilas A, Michael IP, Grass L, Soosaipillai A, Rosen B, Murphy J, Diamandis EP. Kallikreins as markers of disseminated tumour cells in ovarian cancer- a pilot study. Tumour Biol. 2006; 27:104-114.

26. Wimberger P, Heubner M, Otterbach F, Fehm T, Kimmig R, Kasimir-Bauer S. Influence of platinum-based chemotherapy on disseminated tumor cells in blood and bone marrow of patients with ovarian cancer. Gynecol Oncol. 2007; 107:331-338.

27. Behbakht K, Sill MW, Darcy KM, Rubin SC, Mannel RS, Waggoner S, Schilder RJ, Cai KQ, Godwin AK, Alpaugh RK. Phase II trial of the mTOR inhibitor, temsirolimus and evaluation of circulating tumor cells and tumor biomarkers in persistent and recurrent epithelial ovarian and primary peritoneal malignancies: a Gynecologic Oncology Group study. Gynecol Oncol. 2011; 123:19-26.

28. Liu JF, Kindelberger D, Doyle C, Lowe A, Barry WT, Matulonis UA. Predictive value of circulating tumor cells (CTCs) in newly-diagnosed and recurrent ovarian cancer patients. Gynecol Oncol. 2013; 131:352-356.

29. Kolostova K, Matkowski R, Jedryka M, Soter K, Cegan M, Pinkas M, Jakabova A, Pavlasek J, Spicka J, Bobek V. The added value of circulating tumor cells examination in ovarian cancer staging. Am J Cancer Res. 2015; 5:3363-3375.

30. Kolostova K, Pinkas M, Jakabova A, Pospisilova E, Svobodova P, Spicka J, Cegan M, Matkowski R, Bobek V. Molecular characterization of circulating tumor cells in ovarian cancer. Am J Cancer Res. 2016; 6:973-980.

31. Hellstrom I, Raycraft J, Hayden-Ledbetter M, Ledbetter JA, Schummer M, McIntosh M, Drescher C, Urban N, Hellstrom KE. The HE4 (WFDC2) protein is a biomarker for ovarian carcinoma. Cancer Res. 2003; 63:3695-3700.

32. Angioli R, Plotti F, Capriglione S, Aloisi A, Montera R, Luvero D, Miranda A, Cafa EV, Damiani P, BenedettiPanici P. Can the preoperative HE4 level predict optimal cytoreduction in patients with advanced ovarian carcinoma? Gynecol Oncol. 2013; 128:579-583.

33. Chang X, Ye X, Dong L, Cheng H, Cheng Y, Zhu L, Liao Q, Zhao Y, Tian L, Fu T, Chen J, Cui H. Human epididymis protein 4 (HE4) as a serum tumor biomarker in patients with ovarian carcinoma. Int J Gynecol Cancer. 2011; 21:852-858.

34. Zou SL, Chang XH, Ye X, Cheng HY, Cheng YX, Tang ZJ, Zhang ZJ, Gao L, Chen XH, Cui H. Effect of human epididymis protein 4 gene silencing on the malignant phenotype in ovarian cancer. Chin Med J (Engl). 2011; 124:3133-3140.

35. Siravegna G, Marsoni S, Siena S, Bardelli A. Integrating liquid biopsies into the management of cancer. Nat Rev Clin Oncol. 2017.

36. Edge SB, Amin MB, Compton CC, Fritz AG, Greene FL, Trotti A. (2010). AJCC cancer staging manual (7th ed). (New York: NY: Springer).

37. Dauplat J, Hacker NF, Nieberg RK, Berek JS, Rose TP, Sagae S. Distant metastases in epithelial ovarian carcinoma. Cancer. 1987; 60:1561-1566.

38. Moore RG, McMeekin DS, Brown AK, DiSilvestro P, Miller MC, Allard WJ, Gajewski W, Kurman R, Bast RC Jr, Skates SJ. A novel multiple marker bioassay utilizing HE4 
and CA125 for the prediction of ovarian cancer in patients with a pelvic mass. Gynecol Oncol. 2009; 112:40-46.

39. Drapkin R, von Horsten HH, Lin Y, Mok SC, Crum CP, Welch WR, Hecht JL. Human epididymis protein 4 (HE4) is a secreted glycoprotein that is overexpressed by serous and endometrioid ovarian carcinomas. Cancer Res. 2005; 65:2162-2169.

40. Chen S, Sun Y, Neoh KH, Chen A, Li W, Yang X, Han RPS. Microfluidic assay of circulating endothelial cells in coronary artery disease patients with angina pectoris. PLoS One. 2017; 12:e0181249.

41. Jiang J, Bo D, Chang X, Cheng H, Ye X, Cui H. Discrepant clinicopathologic characteristics and HE4 performance in type I and type II epithelial ovarian cancer. Int J Clin Exp Med. 2015; 8:21303-21310. 